\title{
$\mathrm{AD}-\mathrm{A} 281784$
}

H. I. W.

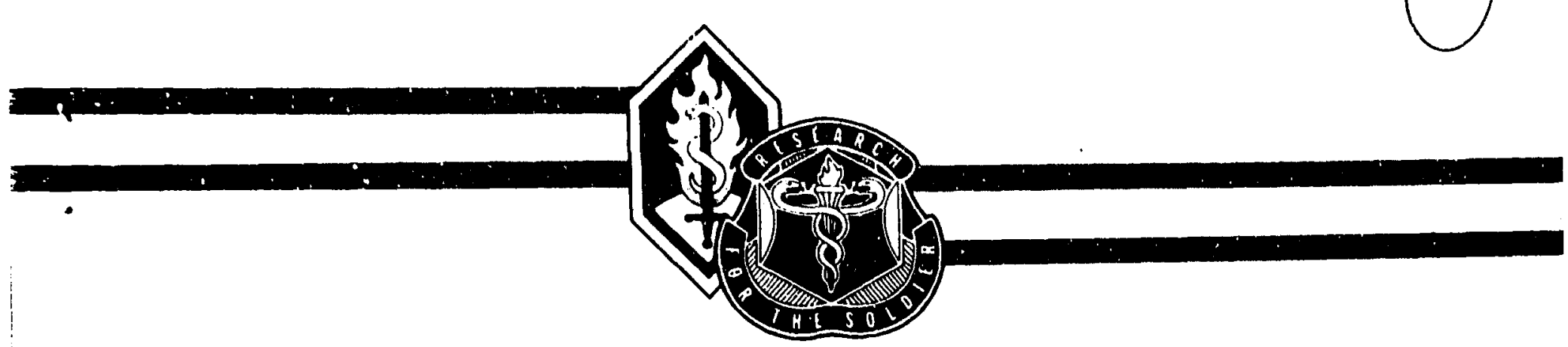

Switching from Forward-Looking Infrared

to Night Vision Goggles:

Transitory Effects

DTIC

$\therefore$ ELECTE

(1) JUL 191994

$=$

E

\section{on Visual Resolution}

(Reprifit)

\section{By}

Jeff Rabin

and

Roger W. Wiley

$94-718$

006

Aircrew Health and Performance Division

LP $94-22386$

June 1994

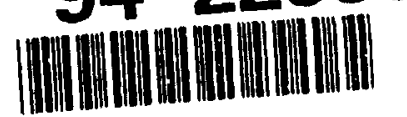

Approved for public rolease; dlatribution unilmited.

United States Army Aeromedical Research Laboratory

Fort Rucker, Alabama 36362-0577 
Notice

Qualified requesters

Qualified requesters may obtain copies from the Defense Technical Information Center (DTIC), Cameron station, Alexandria, Virginia 22314. Orders will be expedited if placed through the librarian or other person designated to request documents from DTIC.

\section{Change of address}

Organizations receiving reports from the U.S. Army Aeromedical Research Iaboratory on automatic mailing lists should confirm correct address when corresponding about laboratory reports.

\section{Disposition}

Destroy this document when it is no longer needed. Do not return it to the originator.

\section{Disclaimer}

The views, opinions, and/or findings contained in this report are those of the author(s) and should not be construed as an official Department of the Army position, policy, or decision, unless so designated by other official documentation. Citation of trade names in this report does not constitute an official Department of the Army endorsement or approval of the use of such commercial items.

Reviewed:

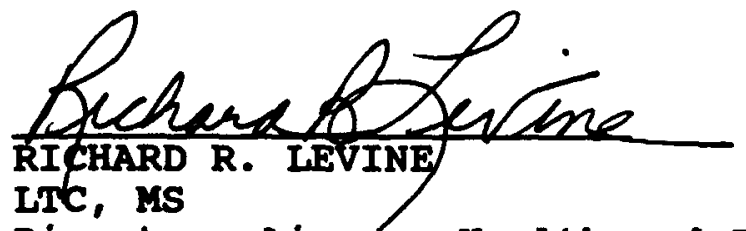

Director, Aircrew Health and Performance Division

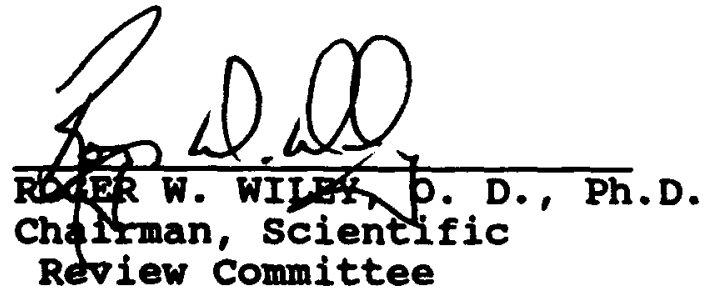

Released for publication:

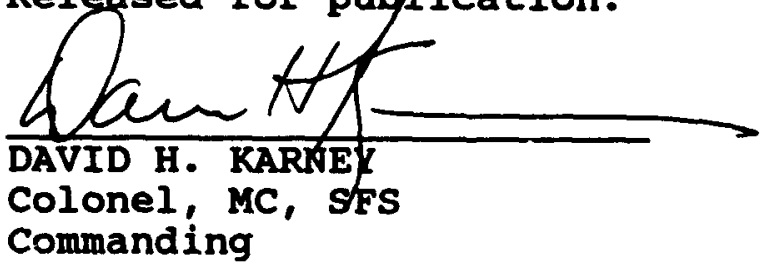




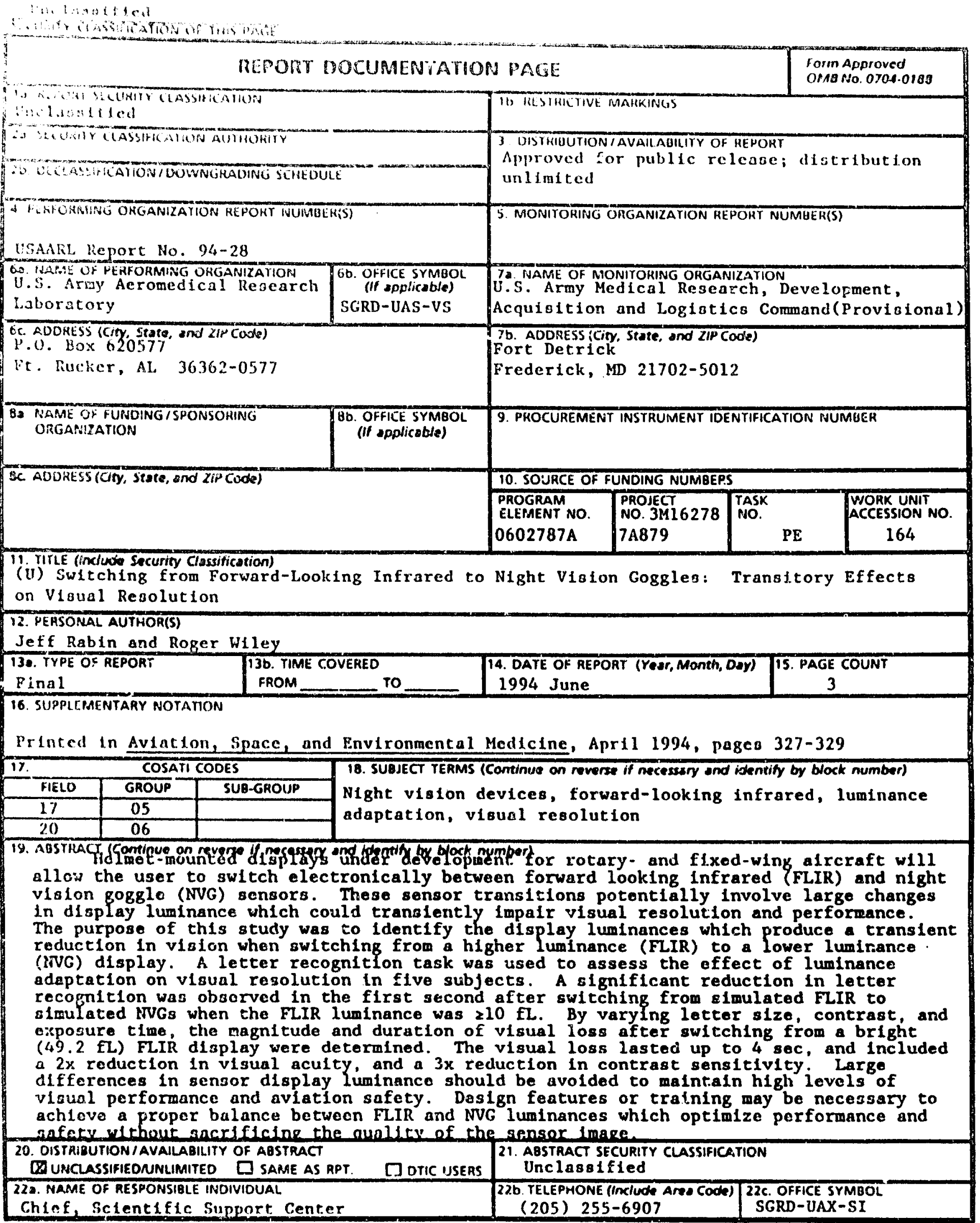

DO Form 1473, IUN $B 6 \quad$ Previous colitions are obsolete.

SECUAITY CLASSIFICATION OF THIS PAGE Unclaseified 
Reprint \& Copyright @ by

Aerospace Medical Association, Alexandria, VA

\section{Switching from Forward-Looking Infrared to Night Vision Goggles: Transitory Effects on Visual Resolution}

Jeff Rabin, O.D., Ph.D., and Roger Wiley, O.D., Ph.D.

RAsin J. WILEY R. Switching from forward-looking infrared to night vision gogeles: iransitory effects on visual resolution. A viat. Space Environ. Med. 1994; 65:327-9.

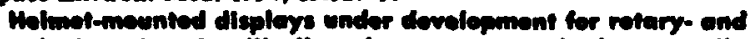
fixed-wing atrereft will allow tho usor so swiph olectronicelly

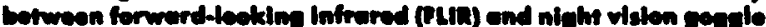

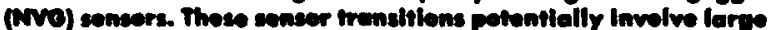

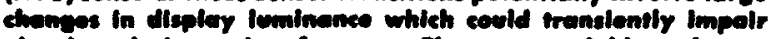
viswal reselustien end performenee. Tho purpose of this shudy was to Kentily the diseloy lominanees whileh produce a trenslont redvetion in vision when switehloy frem a higher Iuminanee

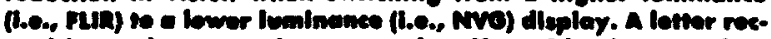

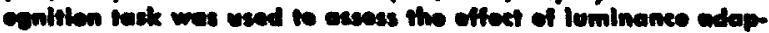

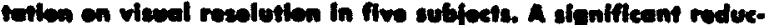

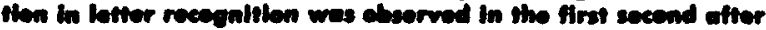

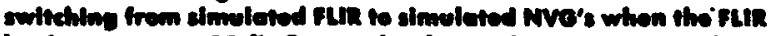

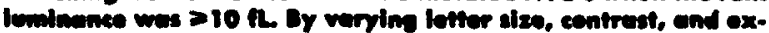

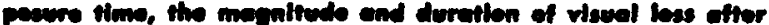

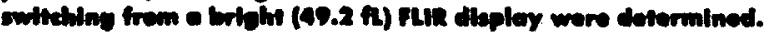

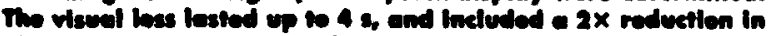

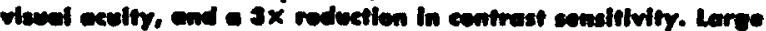

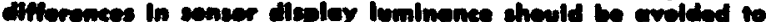

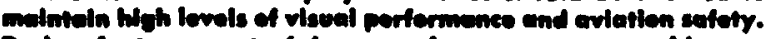

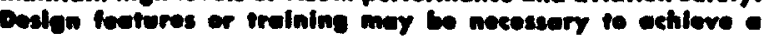

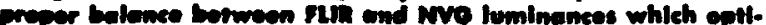

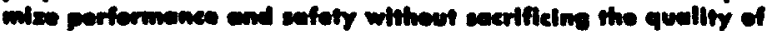
the seveser lnowe.

TELMET-MOUNTED displays being developed for 1 rotary-and fixed-wing aircraft will allow the user to electronically switch between forward-looking infrared (FLIR) and night vision goggle (NVG) sensors. Since these sensors respond to different portions of the infrared spectrum, the capacity for rapid switching will allow performance over a greater range of environmental conditions. While NVG and FLIR displays will be

From the U.S. Army Aeronedical Research Lubontory, Airerew Health and Performance Division, Fort Rucker, AL.

This munuseript was received for review in March 1993. It was revined in June and July 1993 and sceepted for publication in July thos.

Ackess repriot requests to Jef Robin, O.D. M.D. who is a revench optonetriat at U.S. Army Aeromedical Research Labontory, Alewew Heath and Performunce Diviaton, Fort Rucker, AL 36362 ⿶77. similar in color and size, they may differ in several respects including perspective, contrast and luminance. Notwithstanding the benefit of switching between sensors, the user will be required to adapt to these different display characteristics.

The luminance of the NVG display is typically in the mesopic to low photopic range (0.3-2.0 fL), and cannot be adjusted by the user. It remains relatively constant in any one night sky condition. In comparison, the luminance of the FLIR display can be adjusted by the user to be nearly $100 \times$ brighter than NVG's $(5,11,12)$. Rapid transitions from a bright FLIR display to a much dimmer NVG display may impose adaptational demands on the visual system that lead to a transient decrement in visual performance $(1,2,10)$.

The purpose of this study was to determine the display luminances that produce a transient reduction in vision after switching from a brighter (FLIR) to a dimmer (NVG) display. Since luminance adaptation involves photochemical and neural events that change over time, vision is also in a state of transition, making measurement of visual performance difficult $(1-3,9,10)$. Thus, in the present study, vision was assessed in discrete intervals following adaptation to simulated FLIR displays. Observers adapted to luminances comparable to FLIR, and then attempted to recognize letters presented at the luminance of an NVG display. By varying letter size, contrast, and exposure time, it was possible to estimate the extent and duration of visual loss after switching from a very bright to a dim display. Recommendations are made regarding the proper balance between FLIR and NVG display luminances.

\section{METHODS}

A letter recognition task was used to evaluate the effect of switching from a bright (simulated FLIR) to a dim (simulated NVG) display. Stimuli were computergenerated and displayed on a color monitor in an otherwise dark room. Luminance was measured with a calibrated photometer and stored in tabular form. Only the

Aviation, Space, and Environmental Medicine - Aprt ISw

327

1

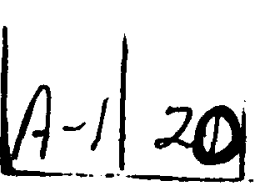

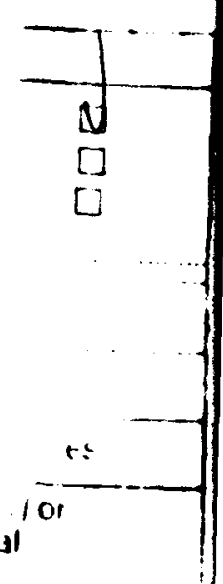


green phosphor of the monitor was used to simulate the ereen displays of NVG's and FLIR. The simulated FLIR display was uniform, green, and subtended an angle of $5^{\circ}$ at a viewing distance of $2.7 \mathrm{~m}$. A small, low contrast cross centered in this display was used to guide fixation. This display, which served as the adaptation field, was replaced periodically by a lower luminance test display (simulated NVG display) consisting of a single letter centered in the screen. The letter was always darker than its background, and the background was held constant at $0.6 \mathrm{fL}$, representing the luminance of an NVG display in moderate ( $Y_{4}$ moon to starlight) night sky conditions. Monocular viewing was used to prevent fluctuations in binocular posture from possibly infuencing the results.

The procedure consisted of having the subject adapt to the simulated FLIR display for $20 \mathrm{~s}$, followed by a I s test interval in which the subject attempted to recognize a single letter centered in the screen at the luminance of NVG's. The adaptation field then reappeared and the adaptation-test cycle was repeated on subsequent trials during which different parameters (adaptation luminance, letter size, contrast, and duration) were varied. In the first session, the luminance of the FLIR display was varied from trial to trial to determine those values which produced an adverse effect on letter recognition with NVG's. The adaptation luminances ranged from 0.6 to $49.2 \mathrm{fL}$ in approximately $3 \times$ steps. Two letter sizes, chosen to be near recognition threshold, were used to assess high contrast (2021 letter; 99.5\% contrast) and low contrast (20/42 letter; $27.1 \%)$ letter recognition. Contrast was expressed as Weber values (background-letter/background $\times 100$ ). Luminances were presented in ascending order to reduce successive adaptation effects.

In separate sessions, letter size, contrast, and exposure duration were varied to determine the magnitude and duration of visual loss following luminance adaptation. The luminance of each $20 \mathrm{~s}$ adaptation display was maintained at the highest level (49.2 IL) while the test field was again $0.6 \mathrm{fL}$. In one session, letter size $(20 / 21$, 20142, 20/84; $99.5 \%$ contrast) and letter contrast (27.1\%, $51.0 \%$, and $99.5 \% ; 20 / 42$ letter) were varied from trial to trial. In a separate session, the duration of letter exposure $(0.5,1,2$ or 4 s) was varied between trials. Each trial was repeated 4 times for each condition (size, contrast, and duration), and the percent correct was determined for each subject.

Five adult volunteers (age 22 to 31 ; mean $=26.4$ years) with normal ocular health and visual acuity corrected with spectacles to $20 / 20$ participated in this study. Following protocol approval by our institutional review board, informed consent was obtained after each subject was briefed on all procedures. Subjects were told they could withdraw at any time.

\section{RESULTS}

Fig. 1 shows the relation between letter recognition on a simulated NVG display after switching from a FLIR display of equal or higher luminance. Mean percent correct (five subjects) is plotted against the lumimace of the adaptation field. Because results with high

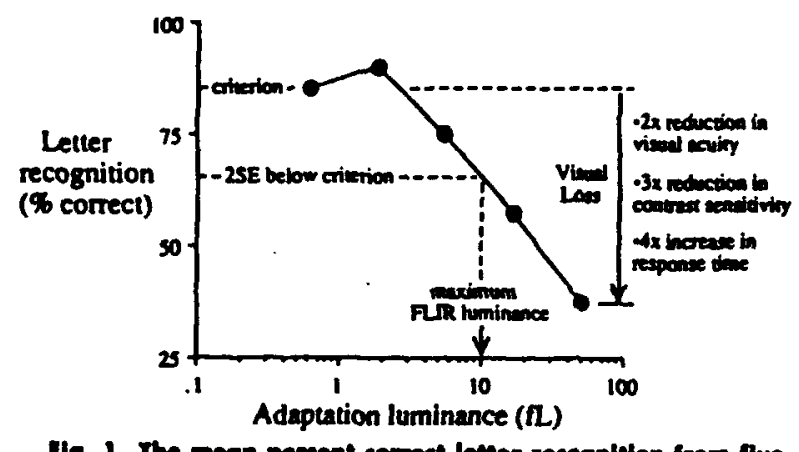

Nig. 1. The mean porcent cerrect letter recegnition from the subjects is plotted egelnst the luminanes of the cdaptention field. The letters were high (99.5\%) and low (27.156) centrast presonied of a Juminance cemparable to an NVo display (0.6 th). while the edoptotien luminanees Included a rance of volues pes. stble with PLIL. The moan pereent cerreet ebrained when teot and adoptetien fiolds were of equal luminence is deneted ertiorten, and the volue 255 bolow the eriterien was used te determine the maximum recemmended his lumlnenee. The everese amoum of translent visual loas whleh eceurred ofter switching frem the highest luminones display (A9.2 H) is Indleoted on the right es reductions In visual eculity and eontrost senstiviry, and as an Inerease in respense Hime.

and low contrast letters were not significantly different $\left(F_{1,0}=2.62 ; p>0.10\right)$, values were averaged across these two conditions. The response obtained with adaptation and test fields of equal luminance ( $85 \%$ correct) is denoted criterion. Fig. 1 shows that as the luminance of the adaptation field was increased, the percentage of correct responses increased slightly and then decreased, falling 2 SE below the criterion when the adaptation luminance was $10 \mathrm{fL}$. This indicates that a transient yet significant reduction in visual resolution of NVG targets can occur after switching from a FLIR display which is $>10 \mathrm{fL}$.

While Fig. I demonstrates the FLIR luminance which is likely to produce transient visual loss after switching to NVG's, the magnitude and duration of this effect are not evident in these results. What is the visual consequence of maintaining the FLIR intensity at a high level if one is to switch from FLIR to NVG's? To explore this issue, letter size; contrast, and exposure duration were varied from trial to trial with adaptation maintained at the highest level (49.2 IL). Thus, we determined the increase in letter size, contrast, and exposure duration necessary to overcome a large luminance adaptation effect. Results are summarized on the right side of Fig. 1 as changes in visual acuity, contrast sensitivity, and response time. Following adaptation to the 49.2 iL field, letter size had to be increased an average of $2 \times(20 / 21$ to 20/42), letter contrast $3 \times(27.1 \%$ to $81.3 \%)$, and exposure duration $4 \times$ (from 1 to 4 s) to overcome the adaptation effect and achieve criterion performance. In terms of both magnitude and duration, these transient visual decrements are nontrivial and stress the importance of maintaining a proper balance between FLIR and NVG display luminances.

\section{DISCUSSION}

The purpose of this study was to determine the display luminances which produce an adverse effect on 


\section{SWIICHING FROM FLIR TO NVG'S-RABIN \& WILEY}

visual resolution aner switching from a higher luminance (FLIR) to a lower luminance (NVG) display. A significant reduction in letter recognition was observed in the first 1 s after switching from simulated FLIR to simulated NVG when the FLIR luminance was $>10 \mathrm{fL}$. By varying letter size, contrast, and exposure duration, it was possible to estimate the magnitude and duration of visual loss after switching from a very bright ( $49.2 \mathrm{fL}$ ) FLIR display. This visual loss, which lasted up to $4 \mathrm{~s}$, included $\mathrm{2} 2 \mathrm{x}$ reduction in visual acuity, and a $3 \times$ reduction in contrast sensitivity.

A transitory reduction in resolution after switching from FLIR to NVG's could interfere with object recognition during critical periods of aircraft control, target acquisition, and firing. It is recommended that large differences in luminance be avoided to optimize visual performance and safety. A FLIR display luminance no ereater than 10 fl should minimize any visual loss after switching to NVG's. Because current and planned FLIR systems have no specific user indications of display luminance, it may be necessary to incorporate a perceptual technique in which the pilot matches the brightness of the two displays to ensure that the luminance difierence is within the recommended range. A neutral density filter of fixed amount before the FLIR display could be used to match brightness within the desired range. Altematively, an intensity indicator could be included in the design. The choice of display luminances also may be governed by other factors, such as the quality of FLIR imagery obtained at different luminances, and under varying environmental conditions.

Since the present study was conducted with simulations of FLIR and NVG displays, caution should be exercised in applying the results direetly to aviation performance. The simulations subtended a considerably smaller area than the actual displays, and lacked the dymamic imagery experienced in flight. However, these factors should not influence local adaptation effects responsible for the visual loss observed in this study $(1,9)$. It is of interest that luminance adaptation produced a slightly greater reduction in contrast sensitivity than vi- sual acuity for letters of similar size $(20 / 20-20 / 40)$. This result, however, may be expected from the shape of the contrast sensitivity function which, for higher spatial frequencies, changes more rapidly for contrast than size $(6,7)$. A clinical application of the present result may be to use small letter contrast sensitivity, rather than acuity, to reveal abnormal luminance adaptation in the clinical photostress recovery test $(4,8)$.

\section{ACKNOWLEDGMENTS}

Grateful acknowledgment is extended to James Wicks and James Bohling for their assistance.

\section{REFERENCES}

1. Boynton RM, Rinalducei EJ, Stemheim C. Visibility losses produced by transient adaptational changes in the range from 0.4 to 4000 R. Illum. Engin. 1969; 61:217-27.

2. Boynton RM, Corwin TR, Sternheim C. Visibility losses prodoced by tiash adaptation. Illum. Engin. 1970; 65:259-66.

3. Dowling JE. Neural and photochemical mechanisms of visual ad. aptation in the rat. J. Gen. Physiol. 1963; 46:1287-301.

4. Glaser IS. Savino PJ, Summers KD. MeDonald SA, Knighton RW. The photostress recovery test in the clinical assessment of visual function. Am. J. Ophthulmol. 197; 83:255-60.

5. Rash CE, Verona RW, Crowley JS. Human factors and safety considerations of night vision systems flipht usins thermal im. arins systems. For Rucker, AL. U.S. Amy Aeromedieal Research Laboratory. 1990; USAARL Report No. 90-10.

6. Robson JG. Spatial and :emporal contrast sensitivity functions of the visual system. J. Opt. Soc. Am. 1966; S6:1141-2.

7. Schade OH. Optical and pholoelectric analos of the eye. J. Opt. Soc. Am. 1957; 46:721-39.

8. Severin SL, Harper JY, Cuiver JF. Pholostress test for the evaluation of macular function. Arch. Ophihalmol. 1963; 70:593-7.

9. Shapley R. Enrolh-Cugell C. Visual adaptation and retinal pain controls. In: Osborme N, Chader G, eds. Promesss in retinal research. Vol. 3. Oxford: Permazon Press, 1944:263-346.

10. Spiker A, Rogers SP. Cicinelli J. Effects of adaplation and display luminance on CRT symbol recognition time. SPIE Advances in Display Technotosy V 1935; 526:13-20.

11. Verona RW. Image intensifiers: past and present. In: AGARD Number 379. Visual protection and enhancement. 1985; Neuilly-sur-Seine, France: NATO-AGARD. C1.1-C1.S.

12. Verona RW, Rash CE. Human fectors and safety considerations of night vision systems flight. Fort Rucker, AL: U.S. Army Aeromedical Research Luboratory. 1989; USAARL Report No. 89-12. 
Initial distribution

Commander, U.S. Army Natick Research, Development and Engineering Center ATTN: SATNC-MIL (Documents Librarian)

Natick, MA 01760-5040

Chairman

National Transportation Safety Board 800 Independence Avenue, S.W.

Washington, DC 20594

Commander

10th Medical Laboratory

ATTN: Audiologist

APO New York 09180

Naval Air Development Center

Technical Information Division

Technical Support Detachment

Warminster, PA 18974

Commanding Officer, Naval Medical

Research and Development Command

National Naval Medical Center

Bethesda, MD 20814-5044

Deputy Director, Defense Research and Engineering

ATTN: Military Assistant for Medical and Life Sciences

Washington, DC 20301-3080

Commander, U.S. Army Research Institute of Environmental Medicine Natick, MA 01760
Library

Naval Submarine Medical Research Lab Box 900, Naval Sub Base

Groton, CT 06349-5900

Executive Director, U.S. Army Human

Research and Engineering Directorate ATTN: Technical Library

Aberdeen Proving Ground, MD 21005

Commander

Man-Machine Integration System

Code 602

Naval Air Development Center

Warminster, PA 18974

Commander

Naval Air Development Center

ATTN: Code 602-B

Warminster, PA 18974

Commanding Officer

Armstrong Laboratory

Wright-Patterson

Air Force Base, OH 45433-6573

Director

Army Audiology and Speech Center

Walter Reed Army Medical Center

Washington, DC 20307-5001

Commander/Director

U.S. Army Combat Surveillance and Target Acquisition Lab

ATTN: SFAE-IEW-JS

Fort Monmouth, NJ 07703-5305 
Director

Federal Aviation Administration

FAA Technical Center

Atlantic City, NJ 08405

Commander, U.S. Army Test and Evaluation Command

ATTN: AMSTE-AD-H

Aberdeen Proving Ground, MD 21005

Naval Air Systems Command

Technical Air Library 950D

Room 278, Jefferson Plaza II

Department of the Navy

Washington, DC 20361

Director

U.S. Army Ballistic

Research Laboratory

ATTN: DRXBR-OD-ST Tech Reports

Aberdeen Proving Ground, MD 21005

Commander

U.S. Army Medical Research

Institute of Chemical Defense

ATTN: SGRD-UV-AO

Aberdeen Proving Ground,

MD 21010-5425

Commander

USAMRDALC

ATTN: SGRD-RMS

Fort Detrick, Frederick, MD 21702-5012

Director

Walter Reed Army Institute of Research

Washington, DC 20307-5100

HQ DA (DASG-PSP-O)

5109 Leesburg Pike

Falls Church, VA 22041-3258
Harry Diamond Laboratories

ATTN: Technical Information Branch 2800 Powder Mill Road

Adelphi, MD 20783-1197

U.S. Army Materiel Systems

Analysis Agency

ATTN: AMXSY-PA (Reports Processing)

Aberdeen Proving Ground

MD 21005-5071

U.S. Army Ordnance Center and School Library

Simpson Hall, Building 3071

Aberdeen Proving Ground, MD 21005

U.S. Army Environmental

Hygiene Agency

ATTN: HSHB-MO-A

Aberdeen Proving Ground, MD 21010

Technical Library Chemical Research and Development Center

Aberdeen Proving Ground, MD

21010-5423

Commander

U.S. Army Medical Research Institute of Infectious Disease

ATTN: SGRD-UIZ-C

Fort Detrick, Frederick, MD 21702

Director, Biologicai

Sciences Division

Office of Naval Research

600 North Quincy Street

Arlington, VA 22217

Commander

U.S. Army Materiel Command

ATTN: AMCDE-XS

5001 Eisenhower Avenue

Alexandria, VA 22333 
Commandant

U.S. Army Aviation

Logistics School ATTN: ATSQ-TDN

Fort Eustis, VA 23604

Headquarters (ATMD)

U.S. Army Training and Doctrine Command

ATTN: ATBO-M

Fort Monroe, VA 23651

IAF Liaison Officer for Safety

USAF Safety Agency/SEFF

9750 Avenue G, SE

Kirtland Air Force Base

NM 87117-5671

Naval Aerospace Medical Institute Library

Building 1953, Code 03L

Pensacola, FL $32508-5600$

Command Surgeon

HQ USCENTCOM (CCSG)

U.S. Central Command

MacDill Air Force Base, FL 33608

Air University Library

(AUL/LSE)

Maxwell Air Force Base, AL 36112

U.S. Air Force Institute of Technology (AFTT/LDEE)

Building 640, Area B

Wright-Patterson

Air Force Base, OH 45433

Henry L. Taylor

Director, Institute of Aviation

University of Illinois-Willard Airport

Savoy, IL 61874
Chief, National Guard Bureau

ATTN: NGB-ARS

Arlington Hall Station

111 South George Mason Drive

Arlington, VA 22204-1382

Commander

U.S. Army Aviation and Troop Command

ATTN: AMSAT-R-ES

4300 Goodfellow Bouvelard

St. Louis, MO 63120-1798

U.S. Army Aviation and Troop Command Library and Information Center Branch ATTN: AMSAV-DIL

4300 Goodfellow Boulevard

St. Louis, MO 63120

Federal Aviation Administration

Civil Aeromedical Institute

Library AAM-400A

P.O. Box 25082

Oklahoma City, OK 73125

Commander

U.S. Army Medical Department and School

ATTN: Library

Fort Sam Houston, TX 78234

Commander

U.S. Army Institute of Surgical Research ATTN: SGRD-USM

Fort Sam Houston, TX 78234-6200

AAMRL/HEX

Wright-Patterson

Air Force Base, OH 45433 
Product Manager

Aviation Life Support Equipment

ATTN: SFAE-AV-LSE

4300 Goodfellow Boulevard

St. Louis, MO 63120-1798

Commander and Director

USAE Waterways Experiment Station

ATTN: CEWES-IM-MI-R,

CD Department

3909 Halls Ferry Road

Vicksburg, MS 39180-6199

Commanding Officer

Naval Biodynamics Laboratory

P.O. Box 24907

New Orleans, LA 70189-0407

Assistant Commandant

U.S. Army Field Artillery School

ATTN: Morris Swott Technical Library

Fort Sill, OK 73503-0312

Mr. Peter Seib

Human Engineering Crew Station

Box 266

Westland Helicopters Limited

Yeovil, Somerset BA20 2YB UK

U.S. Army Dugway Proving Ground

Technical Library, Building 5330

Dugway, UT 84022

U.S. Army Yuma Proving Ground

Technical Library

Yuma, AZ 85364

AFFTC Technical Library

$6510 \mathrm{TW} / \mathrm{TSTL}$

Edwards Air Force Base,

CA 93523-5000
Commander

Code 3431

Naval Weapons Center

China Lake, CA 93555

Aeromechanics Laboratory

U.S. Army Research and Technical Labs Ames Research Center, M/S 215-1

Moffett Field, CA 94035

Sixth U.S. Army

ATTN: SMA

Presidio of San Francisco, CA 94129

Commander

U.S. Army Aeromedical Center

Fort Rucker, AL 36362

Strughold Aeromedical Library

Document Service Section

2511 Kennedy Circle

Brooks Air Force Base, TX 78235-5122

Dr. Diane Damos

Department of Human Factors

ISSM, USC

Los Angeles, CA 90089-0021

U.S. Army White Sands

Missile Range

ATTN: STEWS-IM-ST

White Sands Missile Range, NM 88002

U.S. Army Aviation Engineering

Flight Activity

ATTN: SAVTE-M (Tech Lib) Stop 217

Edwards Air Force Base, CA 93523-5000

Ms. Sandra G. Hart

Ames Research Center

MS 262-3

Moffett Field, CA 94035 
Commander

USAMRDALC

ATTN: SGRD-UMZ

Fort Detrick, Frederick, MD 21702-5009

Commander

U.S. Army Health Services Command

ATTN: HSOP-SO

Fort Sam Houston, TX 78234-6000

U. S. Army Research Institute

Aviation R\&D Activity

ATTN: PERI-IR

Fort Rucker, AL 36362

Commander

U.S. Army Safety Center

Fort Rucker, AL 36362

U.S. Army Aircraft Development Test Activity

ATTN: STEBG-MP.P

Cairns Army Air Field

Fort Rucker, AL 36362

Commander

USAMRDALC

ATTN: SGRD-PLC (COL R. Gifford)

Fort Detrick, Frederick, MD 21702

TRADOC Aviation LO

Unit 21551, Box A-209-A

APO AE 09777

Netherlands Army Liaison Office

Building 602

Fort Rucker, AL 36362

British Army Liaison Office

Building 602

Fort Rucker, AL 36362
Italian Army Liaison Office

Building 602

Fort Rucker, AL 36362

Directorate of Training Development

Building 502

Fort Rucker, AL 36362

Chief

USAHEL/USAAVNC Field Office

P. O. Box 716

Fort Rucker, AL 36362-5349

Commander, U.S. Army Aviation Center and Fort Rucker

ATTN: ATZQ-CG

Fort Rucker, AL 36362

Chief

Test \& Evaluation Coordinating Board

Cairns Army Air Field

Fort Rucker, AL 36362

Canadian Army Liaison Office

Building 602

Fort Rucker, AL 36362

German Army Liaison Office

Building 602

Fort Rucker, AL 36362

French Army Liaison Office

USAAVNC (Building 602)

Fort Rucker, AL 36362-5021

Australian Army Liaison Office

Building 602

Fort Rucker, AL 36362

Dr. Garrison Rapmund

6 Burning Tree Court

Bethesda, MD 20817 
Commandant, Royal Air Force

Institute of Aviation Medicine

Farnborough, Hampshire GU14 6SZ UK

Defense Technical Information

Cameron Station, Building 5

Alexandra, VA 22304-6145

Commander, U.S. Army Foreign Science and Technology Center

AIFRTA (Davis)

2207 th Street, NE

Charlottesville, VA 22901-5396

Commander

Applied Technology Laboratory

USARTL-ATCOM

ATTN: Library, Building 401

Fort Eustis, VA 23604

Commander, U.S. Air Force

Development Test Center

101 West D Avenue, Suite 117

Eglin Air Force Base, FL 32542-5495

Aviation Medicine Clinic

TMC \#22, SAAF

Fort Bragg, NC 28305

Dr. H. Dix Christensen

Bio-Medical Science Building, Room 753

Post Office Box 26901

Oklahoma City, OK 73190

Commander, U.S. Army Missile

Command

Redstone Scientific Information Center

ATTN: AMSMI-RD-CS-R

/IIL Documents

Redstone Arsenal, AL 35898
Director

Army Personnel Research Establishment

Farnborough, Hants GU14 6SZ UK

U.S. Army Research and Technology Laboratories (AVSCOM)

Propulsion Laboratory MS 302-2

NASA Lewis Research Center

Cleveland, $\mathrm{OH} 44135$

Commander

USAMRDALC

ATTN: SGRD-ZC (COL John F. Glenn)

Fort Detrick, Frederick, MD 21702-5012

Dr. Eugene S. Channing

166 Baughman's Lane

Frederick, MD 21702-4083

U.S. Army Medical Department and School

USAMRDALC Liaison

ATTN: HSMC-FR

Fort Sam Houston, TX 78234

Dr. A. Kornfield

895 Head Street

San Francisco, CA 94132-2813

NVESD

AMSEL-RD-NV-ASID-PST

(Attn: Trang Bui)

10221 Burbeck Road

Fort Belvior, VA 22060-5806

CA Av Med

HQ DAAC

Middle Wallop

Stockbridge, Hants S020 8DY UK 
Dr. Christine Schlichting

Behavioral Sciences Department

Box 900, NAVUBASE NLON

Groton, CT 06349-5900

Commander, HQ AAC/SGPA

Aerospace Medicine Branch

162 Dodd Boulevard, Suite 100

Langley Air Force Base,

VA 23665-1995

Commander

Aviation Applied Technology Directorate

ATTN: AMSAT-R-TV

Fort Eustis, VA 23604-5577

COL Yehezkel G. Caine, MD

Surgeon General, Israel Air Force

Aeromedical Center Library

P. O. Box 02166 I.D.F.

Israel
Director

Aviation Research, Development and Engineering Center

ATTN: AMSAT-R-Z

4300 Goodfellow Boulevard

St. Louis, MO 63120-1798

Commander

USAMRDALC

ATTN: SGRD-ZB (COL C. Fred Tyner)

Fort Detrick, Frederick, MD 21702-5012

Director

Directorate of Combat Developments

ATTN: ATZQ-CD

Building 515

Fort Rucker, AL 36362 